\title{
INFLUENCE OF PLASTIC MULCH ON DAMAGE AND YIELD OF YAM TUBER BY YAM BEETLES (HETEROLIGUS SPP.) IN DELTA STATE, NIGERIA
}

F.O. TOBIH AND L.U. OKONMAH

(Received 11, July 2008; Revision Accepted 8, June 2009)

\author{
ABSTRACT
}

The effects of plastic mulch on damage and yield of yam tuber by yam beetles were investigated at two locations in 2005 and 2006 cropping seasons in Delta State. Trials were laid out in Randomized Complete Block Design with three treatments: black plastic mulch, white plastic mulch and as unprotected control plot which were replicated three times. Data collected were, the number, depth and diameter of feeding holes on yam tuber (Dioscorea rotundata cv adaka), tuber yield and percentage yield increase over control as well as percentage tuber attacked and damage scores. The plastic mulch protected plots had positive impact on tuber yields as indicated by the relatively high percentage yield increase over control which ranged from $23 \%-66 \%$. It was generally observed that plastic mulch protected plots were significantly different $(P \leq 0.05)$ from the control in all the locations and year of cropping. Investigation revealed that white and black plastic mulches were not very effective against the beetle devastation but offered some protection.

KEY WORDS: Plastic mulch, yam beetle, damage, yield.

\section{INTRODUCTION}

Mulching is the practice of placing layer of materials either organic or inorganic on the soil surface to reducing the soil temperature and conserve soil water (Simpson, 1987). Mulching is also commonly practiced in gardening. (Whiting, et al., 2005). The practice prevents soil erosion, baking of the soil surface, acts as an insulation and buffer, moderating the effect of weather, soil temperature and activities of the soil biological agents (Onwueme, 1978; Foster, 1984; Ikeorgu and Ezumah, 1991). Utilization of different mulching materials may result in varied influences on crop growth development and yield (Zaragoza, 2002). Commonly used mulching materials are dry leaves; grass straws, decomposed manures, synthetic mulching materials such as black, white polythene, clear and porous plastics (Mathew and Karikari, 1990). International Institute for Tropical Agric (IITA) has introduced the use of plastic mulch as part of the technical package for seed yam production (Otoo et al., 1987). Investigation by IITA Researchers revealed that the yield of seed yam obtained with white polyethylene mulch laid above the black one was over $33 \%$ higher than when only black polyethylene mulch was used; and $100 \%$ increase when compared with unprotected plots in a yam cropping system (IITA, 1986). The commonest and most abundant mulch materials available to the small-scale and peasant farmers in the developing countries are the grasses. Organic mulch could be incorporated into the soil after harvesting, thus adding nutrients to the soil for the benefit of the subsequent crops (Acquaach, 2005).
Generally, mulching increases soil nutrients, moderate soil temperature, conserves soil water, increases water infiltration, suppresses weed which subsequently results in higher crop yields (Kang et al.,1990). Mulching with grass chippings was reported to consistently increase the yield of cauliflower and reduced damage by brassica root maggots Delia spp. (Hellquist, 1996).

Little or no information is available on the use of plastic mulch to control insect pests, though it has been widely used to control weeds in developed countries. This may not be practicable particularly in the developing world due to economic implications (Campliglia, et al.,2000). The objective of this investigation was to assess the influence of different types of plastic mulch on damage and tuber yield by yam beetle in a yam cropping system.

\section{MATERIALS AND METHODS}

The investigation was carried out at the Faculty of Agriculture Teaching and Research Farm, Delta State University, Asaba campus as well as other at Ugbolu, a village located in Oshimili North Local Government Area of Delta State in 2005 and 2006. A five-year fallowed sites dominated by Chromolaena odorata, Ageratum conizoides and some Tridax spp were chosen for the experiments. The fields at both locations were cleared, demarcated into plots and yam mounds of medium sizes were made with Abakaliki traditional hoe (Ikeorgu and Igwilo, 2002). The gross experimental area was $15 \mathrm{~m} \mathrm{x}$ $12 \mathrm{~m}\left(180 \mathrm{~m}^{2}\right)$ consisting of three treatments namely; black plastic mulch, white plastic mulch and the control

F.O. Tobih, Department of Agronomy, Delta State University, Asaba Campus

L.U. Okonmah, Department of Agronomy, Delta State University, Asaba Campus 
(no plastic mulch). Nine plots of $4 \mathrm{~m} \times 3 \mathrm{~m}$ with $1 \mathrm{~m}$ path were demarcated with the treatments assigned to them in a Randomized Complete Block Design and replicated three times. The mulch materials were obtained from the International Institute for Tropical Agriculture (IITA) Ibadan. Yam setts (Dioscorea rotundata cv adaka) weighing $200-250 \mathrm{~g}$ were planted in mounds spaced $1 \mathrm{~m}$ $x 1 \mathrm{~m}$ apart at the rate of one sett per mound on May 2223, in 2005 and May 13-15, in 2006. The mulch materials were spread uniformly to cover the entire yam heaps or mounds with small opening of about $2 \mathrm{~cm}$ wide at the crest to allow sprouting of the vine as the treatments were applied immediately after planting. The materials were reinforced with ball of soils both at the crest and all round the mounds to prevent exposure and tearing of the materials by winds, rain drops or rodents. After sprouting and vine establishment, staking was done using $2.5 \mathrm{~m}$ Indian bamboo stakes one per mound while the plots were kept weed free manually through hoeing at 3,8 and 12 weeks after planting. No fertilizer of any kind was applied.

At harvest (December, 20-21 in 2005 and December in 2006), the weight of freshly harvested tubers were recorded and yam beetle damage quantified as the number, depth and diameter of feeding holes per tuber. Percentage tuber attacked severity of damage and percentage yield increase over the control was computed. Severity damage was based on Agbaje et al.,(2000) rating where: $1=$ no damage; 2 = mild damage; 3 = moderate damage; 4 = severe damage; 5 $=\mathrm{V}$. severe damage. Data were subjected to statistical analysis of variance (ANOVA) and significantly different means were separated by Fisher's Least Significant Difference (F-LSD) at $5 \%$ probability level.

\section{RESULTS AND DISCUSSION}

The results showing the effects of application of plastic mulch on beetle damage and tuber yields are shown on Tables 1 and 2. There were no significant differences in damage indices particularly in depth and diameter of beetle infestation among the treatments. The damage were however apparently higher in the unprotected control plots than the protected ones. Tuber yields were significantly higher in plots with black plastic mulch $\left(17.8 \mathrm{t} / \mathrm{ha}^{-1}\right)$ as against $15.66 \mathrm{t} / \mathrm{ha}^{-1}$ and $10.70 \mathrm{t} / \mathrm{ha}^{-1}$ recorded for white and unprotected control plots respectively in 2005 at Asaba. Plastic mulch protected plots had varied numbers beetle feeding holes which differed significantly in the two years investigations with black mulch showing greater positive influence than the white (Table 1). Beetle feeding hole numbers were however significantly $(P \leq 0.05)$ lower in plastic mulch protected plots compared to unprotected plots at both locations in 2005 and 2006. At Asaba, mulched plots had least damage indices compared to the control plots which had significantly severe damage. Results from Ugbolu (Table 2) indicated very negligible damages in all plots protected with plastic mulch while the unprotected plots had significant beetle damages.

The tuber yields in protected plots at Asaba were significantly higher than the control both in 2005 and 2006. The same trend was observed at Ugbolu location (Table 2) except the white plastic mulched plots which had tuber yields significantly $(P \leq 0.05)$ lower than the controls. The apparent higher yields in the plastic mulched plots at both locations may partly be attributed to reduction in beetle damage on the tuber, weed interference, better nutrients conservation and uptake, reduced escape of volatile nutrients and increase in the activites of soil micro and macro-organism (Onwueme, 1978; Ikeorgu and Ezumah, 1991; Hellquist, 1996; Acquaach, 2005). Percentage tuber yield increase over control gave between $46 \%-66 \%$ and $37 \%-38 \%$ at Asaba in 2005 and 2006 respectively (Table 1). The influence of the plastic mulch on yield was less pronounced at Ugbolu where yield increase of $13 \%$ and $21 \%$ was recorded in 2005 but was depressed to $-23 \%$ with black plastic mulch in 2006. The cause of the depression in yield could not be ascertained but may be due to natural phenomenon. Other damage indices evaluated such as percentage tuber attacked and damage scores showed that protected plots suffered less damage than the controls.

The result obtained in the study was consistent with the technical package report by IITA where over $33 \%$ tuber yield was obtained using white polyethylene mulch above the black one below which gave about $100 \%$ yield higher than the unprotected plots in a yam cropping system (IITA, 1986). In this study, over $66 \%$ yield increase in some cases was recorded over the protected control plots.

Table 3 showed the interaction between locations and treatments while Table 4 indicated interaction amongst, locations, treatments and year of cropping. Protected plots had higher tuber yields than the unprotected controls while damage indices like beetle feeding holes, depth, diameter and percentage tuber attacked were more in the controls than mulched plots. The relatively high values of coefficient of variation (cv) recorded for the feeding holes across the locations and cropping periods may be attributed to population density of the beetle which is subjected to natural fluctuation and environmental factors such as temperature, humidity, rainfall etc. This was earlier reported by Amugo and Emosairue (2005), who observed that control of stem borer infestation of upland rice in south-eastern Nigeria fluctuate from year to year. It was further reported that the borer population and their natural infestation was climate dependant.

\section{CONCLUSION}

Plastic mulch plots performed generally better than unprotected plots in terms of yam yields and quality. The method is however not only uneconomical but not an effective means of managing yam beetle devastation. More research work is needed in this direction of using plastic mulch to control soil insect pests such as yam beetles. 
Table 1: Effect of Plastic on Yam Beetle damage and Tuber Yield at Asaba.

Treatments

\begin{tabular}{|c|c|c|c|}
\hline $\begin{array}{l}\text { Tuber } \\
\text { Yield }\end{array}$ & $\begin{array}{l}\text { Mean No. of } \\
\text { feeding }\end{array}$ & feeding hole $(\mathrm{cm})$ & $\begin{array}{l}\% \text { Tuber } \\
\text { attacked }\end{array}$ \\
\hline$(\mathrm{t} / \mathrm{ha}-1)$ & tuber & $\mathrm{De}$ & eter \\
\hline
\end{tabular}

$\begin{array}{ll}\text { Damage } & \begin{array}{l}\text { \% Yield } \\ \text { severity }\end{array} \\ & \begin{array}{l}\text { increase } \\ \text { over }\end{array}\end{array}$

Control

2005

\begin{tabular}{|c|c|c|c|c|c|c|c|}
\hline Control & 10.70 & 8.08 & 1.01 & 1.38 & 81.33 & 4.66 & 0 \\
\hline Black & 17.80 & 4.21 & 0.96 & 1.05 & 62.33 & 3.33 & 66.3 \\
\hline White & 15.66 & 3.54 & 1.05 & 1.29 & 64.33 & 3.33 & 46.3 \\
\hline F-LSD $\quad(0.05)$ & 0.79 & 7.59 & 0.33 & 0.92 & 8.87 & 1.19 & \\
\hline CV $(\%)$ & 23.77 & 63.5 & 14.53 & 32.74 & 5.64 & 13.95 & \\
\hline $\mathrm{SE}( \pm)$ & 0.12 & 11.23 & 0.02 & 0.16 & 15.33 & 0.27 & \\
\hline & & & 2006 & & & & \\
\hline Control & 9.30 & 8.40 & 1.19 & 1.15 & 78.33 & 4.00 & 0 \\
\hline Black & 12.80 & 4.70 & 0.61 & 1.15 & 69.00 & 3.33 & 37.6 \\
\hline White & 12.90 & 2.46 & 0.99 & 0.91 & 65.00 & 3.00 & 38.70 \\
\hline F-LSD (0.05) & 0.64 & 2.37 & 0.48 & 0.58 & 18.19 & 1.77 & \\
\hline $\mathrm{CV}(\%)$ & 24.20 & 20.20 & 22.79 & 24.15 & 11.34 & 22.69 & \\
\hline $\operatorname{SE}( \pm)$ & 0.08 & 1.09 & 0.04 & 0.06 & 64.44 & 0.61 & \\
\hline
\end{tabular}

Table 2: Effect of Plastic on Yam Beetle damage and Tuber Yield at Ugbolu

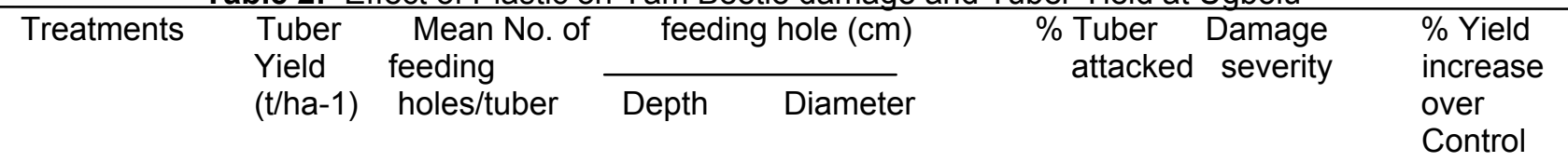

2005

\begin{tabular}{|c|c|c|c|c|c|c|c|}
\hline Control & 9.80 & 7.41 & 0.98 & 1.40 & 83.33 & 4.66 & 0 \\
\hline Black & 11.9 & 1.67 & 0.75 & 1.16 & 65.00 & 3.66 & 21.4 \\
\hline White & 11.1 & 2.00 & 0.94 & 1.11 & 61.66 & 3.66 & 13.3 \\
\hline F-LSD $(0.05)$ & 0.16 & 3.69 & 2.78 & 0.66 & 24.76 & 2.06 & \\
\hline CV $(\%)$ & 6.61 & 44.11 & 28.44 & 23.83 & 15.59 & 22.82 & \\
\hline $\mathrm{SE}( \pm)$ & 0.00 & 2.65 & 0.06 & 0.08 & 119.16 & 0.83 & \\
\hline \multicolumn{8}{|c|}{2006} \\
\hline Control & 9.00 & 4.70 & 1.08 & 1.50 & 74.00 & 4.00 & 0 \\
\hline Black & 6.93 & 2.33 & 1.01 & 1.30 & 66.66 & 3.66 & -23.00 \\
\hline White & 10.5 & 2.16 & 0.82 & 1.36 & 60.33 & 3.66 & 19.70 \\
\hline F-LSD (0.05) & 0.77 & 2.28 & 0.57 & 0.47 & 15.48 & 1.19 & \\
\hline CV (\%) & 38.92 & 32.87 & 26.24 & 15.17 & 10.19 & 13.95 & \\
\hline $\operatorname{SE}( \pm)$ & 0.11 & 1.01 & 0.06 & 0.04 & 46.66 & 0.27 & \\
\hline
\end{tabular}

Table 3: Interaction between location and treatment on yam beetle damage and tuber yield using plastic mulch as control

\begin{tabular}{llllll}
\hline Treatments & $\begin{array}{l}\text { Tuber } \\
\text { Yield } \\
\text { (t/ha-1) }\end{array}$ & $\begin{array}{l}\text { Mean No. of } \\
\text { feeding }\end{array}$ & feeding hole $(\mathrm{cm})$ & \% Tuber & Damage \\
& attacked & Depth & Diameter & & severity
\end{tabular}

2005

Control x location

Black x location

White $\mathrm{x}$ location

F-LSD (0.05)

CV $(\%)$

$\mathrm{SE}( \pm)$

$\begin{array}{ccc}10.25 & 7.74 & 1.00 \\ 14.88 & 2.94 & 0.85 \\ 13.50 & 2.77 & 0.99 \\ 0.30 & 3.97 & 0.25 \\ 18.30 & 67.87 & 21.12 \\ 0.05 & 9.27 & 0.04\end{array}$

13.9

1.08

1.22

0.46

29.48

0.13
4.66

3.50

3.50

0.98

19.73

0.58 


$\begin{array}{lllllll} & & & 2006 & & \\ \text { Control x location } & 9.10 & 6.55 & 1.13 & 1329 & 76.16 & 4.00 \\ \text { Black x location } & 9.88 & 3.51 & 0.71 & 1.10 & 65.83 & 3.50 \\ \text { White x location } & 11.70 & 2.31 & 1.00 & 1.25 & 64.66 & 3.33 \\ \text { F-LSD (0.05) } & 0.39 & 1.32 & 0.03 & 0.28 & 10.26 & 0.98 \\ \text { CV }(\%) & 29.81 & 24.96 & 24.71 & 17.79 & 11.58 & 21.25 \\ \text { SE }( \pm) & 0.09 & 1.06 & 0.05 & 0.04 & 63.65 & 0.58\end{array}$

Table 4: Interaction between treatment, location and years on yam beetle damage and tuber yield using plastic mulch as control

\begin{tabular}{|c|c|c|c|c|c|c|}
\hline \multirow[t]{2}{*}{ Treatments } & \multirow{2}{*}{$\begin{array}{l}\text { Tuber } \\
\text { Yield } \\
\text { (t/ha-1) }\end{array}$} & \multirow{2}{*}{$\begin{array}{l}\text { Mean No. of } \\
\text { feeding } \\
\text { holes/tuber }\end{array}$} & \multicolumn{2}{|c|}{ feeding hole $(\mathrm{cm})$} & \multirow{2}{*}{$\begin{array}{l}\% \text { Tuber } \\
\text { attacked }\end{array}$} & \multirow{2}{*}{$\begin{array}{l}\text { Damage } \\
\text { severity }\end{array}$} \\
\hline & & & Depth & Diameter & & \\
\hline
\end{tabular}

$\begin{array}{lccccrr}\text { Control x location x year } & 9.70 & 7.14 & 1.06 & 1.36 & 79.25 & 4.33 \\ \text { Black x location x year } & 12.38 & 3.22 & 0.78 & 1.09 & 64.75 & 3.50 \\ \text { White x location x year } & 12.60 & 2.54 & 1.00 & 1.24 & 63.83 & 3.41 \\ \text { F-LSD (0.05) } & 0.23 & 1.77 & 0.18 & 0.23 & 7.03 & 0.57 \\ \text { CV }(\%) & 23.74 & 49.08 & 23.58 & 22.75 & 12.12 & 18.36 \\ \text { SE }( \pm) & 0.07 & 4.46 & 0.05 & 0.07 & 70.56 & 4.47\end{array}$

\section{REFERENCES}

Acquaach, G., 2005. Principles of Crop Production: Pearson Prentice Hall, New Jersey United State of America.

Agbaje, G.O., Adegbite, A.A., Akinlosotu, T.A Soyinka S.A., 2002. Performance of new hybrid yam (Dioscorea rotundata poir) varieties under different cropping system. African Journal of Root and Tuber Crops 5(1):8-11.

Amugi, G.O. and Emosairue, S.O., 2005. The effect of furadan $3 \mathrm{G}$ and Lamdacyhalothrim (Karate 2.5 $\mathrm{EC}$ ) on the control of stem borer infestation in upland rice in South-eastern Nigeria. Journal of Sustainable Agriculture and the Environment 7(2): 146-153.

Campligha, E., Temperini, O. and Damato, G., 2000. Effects of soil solarisation on weed control of vegetable crops and on cauliflower and fennel production in the open air. 8thh International symposium on timing of field production in vegetable crops. Bari, Italy Acta Horticulture 533: 249-255.

Foster, L., 1984. Gardening Techniques. Robert L. Lacopi Publications San Francisco. United State of America Pp 15-51.

Hellquist, S., 1996. Mulching with grass chipping in cauliflower, effect on yield and brassica root flies (Delia spp). International Journal of Pest management. 42 (1): 39-46.

IITA (International Institute of Tropical Agriculture), 1986. Annual report and Research Highlights. Ibadan Nigeria. Pp. 86-87.
Ikeorgu, J.E.G. and Ezumah, H.C., 1991. Some analytical aspects of cassava/ maize/ okra/egusi melon complex mixture/ soil temperature in relation to area variation. Field Crops Research 27: 51-60

Ikeorgu, J.E.G. and Igwilo, H.N., 2002. Effect of mulching and staking on yam growth under irrigation during the dry season in Umudike, South Eastern Nigeria. Journal of Sustainable Agriculture and Environment 4 (1): 129-132

Kang, B.T., Reynolds, L. and Atta Krah, A.N., 1990. Alley farming (IITA Reprints). In: Advances in Agronomy, Academic Press Inc. San Diego, USA 43: 315-359.

Matthew, I.P. and Karikari, S.K., 1990. Horticulture; Principles and practices Macmillan Press Ltd London.

Onwueme, I.C., 1978. The Tropical Root and Tuber Crops: Yams, Cassava, Sweet Potato and Cocoyams John Wiley and Sons. New York. $234 \mathrm{pp}$.

Otoo, J.A., Osiru D.S.O., Ngi, S.Y.C. and Hahn, S.K., 1987. Improved technology for seed yam production. International Institute of Tropical Agriculture, Ibadan, Nigeria 57 pp.

Simpson, J.G., 1987. Small gardens, a South Africa guide. C. Struik (Pty) Ltd, Cape Town. Pp 1-75

Whiting, D., Tolan, R. Mechan, B. and Bauer, M., 2005: Colorado Stated University Extension Horticulture Colorado State University, Colorado. www.ext.colostate.edu/pubs/gard. 
Zaragoza, C., 2002. Weed management in vegetable food and agricultural Organization of the United Nations. Plant Production and Protection Paper. Addendum I Rome 34pp. 